\title{
Wound Healing: From Epidermis Culture to Tissue Engineering
}

\author{
Alicia Lorenti ${ }^{1,2}$ \\ ${ }^{1}$ Research Area, Fundación del Quemado Dr. Fortunato Benaim, Buenos Aires, Argentina \\ ${ }^{2}$ Tissue Engineering Department, Fundación Biotar, Banco de Tejidos, Rosario, Argentina \\ Email: alicia.lorenti@gmail.com
}

Received August 28, 2012; revised September 30, 2012; accepted October 15, 2012

\begin{abstract}
The skin is the largest organ of the individual, being the interface between the body and the microenvironment. In severely burned patients and other diseases, the physiological processes of wound healing are not sufficient to complete the closure of their wounds. The in vitro culture of autologous epidermis, which has represented the beginning of Tissue Engineering, is a valuable tool for the treatment of these patients. Keratinocytes can be cultured and stratified in vitro, and an entire epidermal sheet can be obtained. The epidermis cells can be amplified in the laboratory from a skin sample to obtain a surface equivalent to that required for each patient. This technology was first used clinically in 1981 and in Argentina since 1991. Wound repair is a complex process that involves dermal and epidermal cells, extracellular matrix, soluble factors and the sum of interactions between them, providing physical, biological and chemical keys capable of guiding cell function. Seeking to improve the results obtained with cultured epidermis, tissue engineering was directed towards the development of substitutes that not only involve epidermis but also the dermal component. The tissue engineered skin and its therapeutic applications reported in this review demonstrate the feasibility and effectiveness of these approaches. It represents a clear benefit in wound healing. Now, focus must be directed on the development of new scaffolds, developed by different technologies, such as polymer science, or nanotechnology, able to be used as templates to direct the growth of cells, in an attempt to better regenerate the lost skin.
\end{abstract}

Keywords: Tissue Engineering; Epidermis Culture; Dermal-Epidermal Substitutes

\section{Introduction}

The skin is the largest organ of mammals, creating a protective separation between the body and its environment. Besides providing a chemical and mechanical barrier, the skin is also responsible for receiving and mediating sensory stimuli and immune reactions. The top layer of skin, the epidermis, has ectodermal origin, while the lower layer, the dermis, originates from the mesoderm and neural crests. The breaking of this barrier can result in the loss of water, electrolytes and proteins, metabolic disorders, immunosupression, infections and other diseases associated or concomitant with skin lesions.

There are numerous situations in which the integrity of the skin is compromised, causing wounds of varying severity, that bring into play the physiological processes of wound healing.

Wound healing is a dynamic and sequential process, arranged in three phases: inflammatory, proliferative and tissue remodelling. The inflammatory period involves the participation of the blood cells and factors such as coagulation cascade, cytokines and growth factors. After this stage is completed, the proliferative and remodelling stages begin; forming a well orchestrated physiologic process, in which migration, proliferation and differentiation of a variety of cell types occur, as well as the synthesis of extracellular matrix components.

In patients who have a large area of the skin affected, and the depth of the lesion reaches the deepest layer, the physiologic process of repair is not sufficient to regenerate the damaged surface, making it necessary to resort to full-thickness autograft [1]. Autografts remain the therapy of choice in current protocols for the care of severely burned patients [2]. However, wound closure with autografts creates new affected surfaces in the donor areas, and in many circumstances, the remaining healthy skin is not enough to cover the burned areas.

Although burn patients are the most common patient population with extensive skin loss, other conditions such as surgical resection of scars, or giant nevus, epidermolysis bullosa, trauma and chronic ulcers from various etiologies, also require replacement therapies. These wounds are stopped in the inflammatory phase due to an imbalance between the production of growth fac- 
tors, which stimulate the cell proliferation, and proteases, generally produced by fibroblasts, that stimulate migration to the wound site. The causes of this imbalance vary and are associated with the excessive presence of proinflammatory cytokines, decreased growth factors, abnormal deposition of collagen and other proteins of the extracellular matrix, alteration of cell proliferation and protein synthesis, and also an increased apoptosis [3,4].

\section{Wound Coverage}

In all patients suffering from severe (extensive and/or deep) skin loss, the treatment goal is to reach the maximum functional capacity and the better aesthetic result that allows the patient to reintegrate into society.

The early resection of largely burned areas, called scarectomy, is front line therapy for patients with extensive and deep burns [5]. This is necessary because the necrotic tissue releases cytokines, inflammatory mediators, and endotoxines, which inhibits the migration of keratinocytes and fibroblasts to the wound, which delays healing and promotes bacterial growth. Infections caused by this process are closely associated with morbidity and mortality of burn patients.

However, the scarectomy of large areas requires the resected areas to be immediately covered with materials that prevent loss of heat, fluids, electrolytes, and proteins, and also prevent contamination and infection. This temporary coverage should be maintained or replaced periodically until the wound bed is in optimal conditions to receive the final treatment, which is the autologous skin. This is a great challenge for patients with a large amount of the body surface area involved.

Various materials can be used as temporary coverage: biological matrices such as skin allografts from skin banks, pig skin xenografts, or human amniotic membrane, membranes made with extracellular matrix proteins such as sheets of collagen or hyaluronic acid, or synthetic materials as nylon mesh, silicones, and others [6-10]. The materials used are intended to avoid or at least reduce water, proteins and heat loss, and also to prevent microbial contamination.

\section{In Vitro Epidermis Culture}

For over three decades, in vitro culture of autologous epidermis, from a small skin biopsy, began to emerge as a valuable tool for the treatment of burn patients and other skin conditions.

Since 1975 autologous keratinocyte sheets began to be cultured in vitro [11-13], and several years later were used for grafting in severely burned patients [14-16].

\section{Tissue Engineering}

Tissue engineering is an emerging discipline in the medical practice of the last twentieth century. It is defined as the application of principles and methods of engineering and life sciences for the development of biological substitutes that restore, maintain or improve the function of damaged tissues It requires input from various scientific disciplines such as medicine, biology, chemistry, physics, engineering, material science and others. This interdisciplinary approach will provide the required knowledge about the close relationship that exists between the organ/tissue function and structure that is needed to develop substitutes for damaged tissue and to restore lost functionality $[17,18]$.

\section{Fundamentals of the Tissue Engineering}

Tissue Engineering is based on two critical components: cells and biomaterials. The challenge of tissue repair or regeneration is the understanding of cell behavior during two physiological processes, organogenesis and healing. Under these circumstances, cells are able to create functional structures using pre-programmed information and signalling [19].

\subsection{The Cells}

The type and origin of cells used in tissue engineering development must be carefully analyzed to ensure that the most appropriate cells are selected. Some of the issues that should be considered: the function and capacity of the cells; the potential adverse effects associated with these cells (antigenicity, tumorigenicity, etc.); the origin of the cells (autologous, homologous, heterologous); methods used for cell isolation; knowledge of microenvironment in which the cells will be located, and responses to the signals generated in this environment; the degree of differentiation that the cells have or will reach (differentiated, progenitors or stem); the availability of these cells to carry out the development; the need for in vitro amplification and the effects produced for this manipulation; the use of animal products during cultivation; the use of biomaterials or bioreactors; mechanical forces which are subject to the cells, and the responses to these forces [20-23].

Cells that can be used in tissue engineering are: stem cells, progenitor cells, or differentiated primary cells. All these categories of cells, in turn, can be derived from adult or embryonic tissues.

Stem cells, which are defined by their self-renewing, undifferentiation, and proliferation capacities, may have different origins: embryonic stem cells, which are derived from the blastocyst inner cell mass (stage 4 - 5 days of gestation in humans), somatic or adult stem cells, located in the organs or tissues of the adult, or iPS cells, which are derived from differentiated adult cells, reprogrammed to embryonic stages. 
Progenitor cells are population of cells derived from stem cells, with greater differentiation, but not fully differentiated, and high proliferation potential, although for shorter periods of times than stem cells.

Finally, differentiated primary cells are directly derived from adult, differentiated and functional tissues or organs.

The isolation of cells by using various isolation methods, such as enzymatic digestions, selection by specific antibodies, centrifugations, etc., produces a set of different cell types, with different degrees of differentiation, and even includes both stem and progenitor cells.

Generally, cells derived from embryonic tissues can survive and proliferate better than those from adults, because they have a lower level of specialization and greater proliferation potential. The adult tissues usually have a higher proportion of non-proliferating cells, the initiation and propagation of in vitro culture are more difficult, and the life span is often shorter.

Embryonic tissues, as well as fetal tissues, have many practical advantages from the laboratory stand point. However, it should be taken into account that such cells will be different from adult cells, and therefore cannot be assumed that they will mature, in vitro, in the appropriate o desired cell types in vitro.

Each particular tissue engineering application will require the selection of one of the above mentioned cell types. There are situations in which stem cells will be the best option, especially when trying to stimulate their differentiation into specific cell types. At other times, manipulation of adult differentiated cells will be necessary, such as the case of the development of a bioartificial organ, where the isolation of cells that already have proper functionality without need of any previous induction is necessary [24-27].

The development of cell culture techniques is an important tool for tissue engineering. The cells to be used must first be manipulated ex vivo, with different objectives, such as amplifying the number of cells, stimulating differentiation or undifferentiation, stimulating the production of a specific protein, inducing phenotypic changes, and even incorporating specific genetic material.

It should be noted that whenever the in vitro manipulation of cells is necessary, the cell phenotype in culture can and usually is different from cells in vivo. The cell environment in vitro is not a physiological environment, and often in these conditions the cells change their phenotype, frequently to less differentiated stages. Also their genotype may become modified, especially after greater number of subcultures. This concept is extremely important to consider and decide what the best working conditions in vitro are, to ensure that the cell alterations will be minimal, reversible, and the original genotype will not altered. It would be expected that these cells will have the ability to differentiate and be functional when the microenvironment in which the cells will be located, stimulate them, either in the late stages of in vitro manipulation, or in vivo.

\subsection{The Biomaterials}

As already mentioned, the second critical component of tissue engineering, are biomaterials. When considering which biomaterials to use, it is necessary to choose between biological, synthetic or hybrid structures, which will facilitate organized tissue repair, and proper remodelling of the implant site, trying to replicate the physiological environment that cells have in vivo.

It also necessary to consider the properties of the biomaterials that need to be analyzed: chemical structure, toxicity, immunogenicity, biodegradability, biocompatibility, availability, behaviour facing the selected cells, the pressures or forces, and the responses to the interactions between these biomaterials and the cells [28].

\subsection{Interactions between Cells and Biomaterials}

The two critical components, cells and biomaterials, are not independent items, but they should be considered as a whole entity. A characteristic microenvironment is created between: all cell types, biomaterials, extracellular matrix components, signals produced by growth factors, hormones, and cytokines, and the contribution of mechanical forces to which the whole set is subjected. The cells are capable of transforming signals from mechanical forces, in biochemical responses. The path of cells can vary between proliferation, differentiation, undifferentiation, migration, apoptosis, etc, and this path is decided in response to these interactions [29,30] (Figure 1).

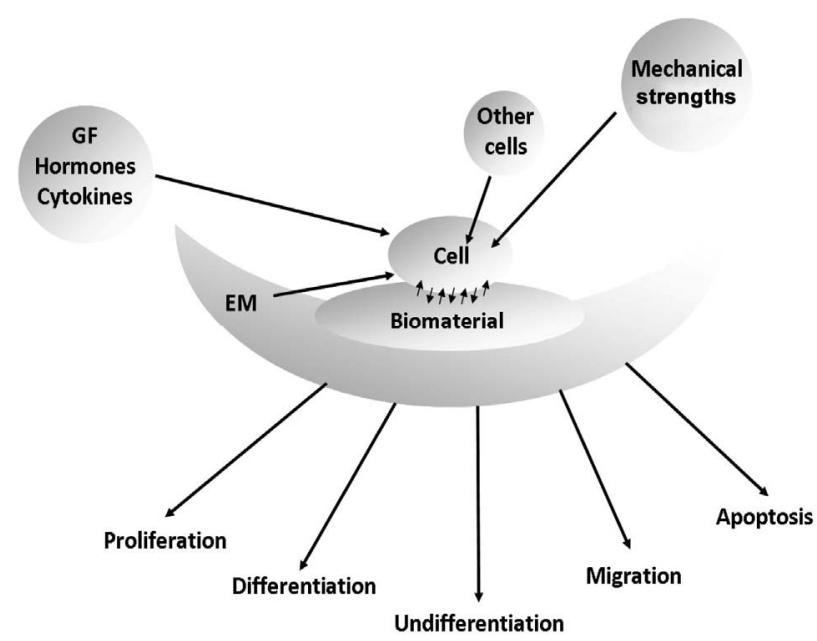

Figure 1. Diagram showing the interactions between all cell types, biomaterials, extracellular matrix (EM), soluble factors (growth factors, hormones, cytokines), mechanical strengths, and the path of the cells as a result of these interactions. 


\section{History of in Vitro Epidermis Culture}

The cultivation of epidermis is the first application of tissue engineering, even before the discipline was defined as such. The amplification of epidermal cells in the laboratory, and their subsequent application on wounds allows for partial or complete restoration of the first and fundamental function of the skin-the barrier to the outside environment. This often makes the difference between the life and death for burned patients. Another large group of patients with ulcers resistant to conventional therapies have been treated using cultured cells, enabling the wound healing process to restart.

In 1950 the in vitro culture of epidermal cells began to be performed, starting from explants of skin placed in vitro, i.e. small pieces of skin placed directly on culture surfaces. However, overgrowth of fibroblasts from the dermis inhibited, rapidly and completely, the development of keratinocytes [31].

Some years later, the keratinocytes were separated from dermal fibroblasts, by enzymatic disaggregation of the skin sample, and then cultured until an epidermal sheet was formed [32].

The first transplantation of cultured epidermal sheets, in an experimental model in rabbits, was performed by Karasek et al., who reported that these sheets had grafted perfectly, forming a stratified epithelium, but, for unknown reasons the graft was lost in a short time [33].

Growing epidermal cells for therapeutic application was a technique described for the first time in 1975 by Rheinwald and Green. This was a key point in the history of epidermis culturing [11-13]. The authors introduced two main modifications: the use of epidermal growth factor (EGF), which increases the proliferation capacity of keratinocytes, and the co-culture with cells from established cell line 3T3, derived from Swiss mouse embryos, as a feeder layer. These cells, that are irradiated to inhibit their proliferation without altering their metabolic capabilities, produce the inhibition of the growth of dermal fibroblasts that normally are present together with the epidermal sample, and provide growth factors necessary for the development of keratinocytes in vitro.

In 1986 Pittelkow et al. introduced a significant modification to this method, by developing a defined culture medium, which allows the culture of keratinocytes without both, feeder layer and fetal bovine serum [34]. These two modifications are particularly important from the point of view of biosafety. It is known that diseases such as bovine spongiform encephalopathy can be transmitted trough the serum of sick animals to humans. Therefore, it is essential to use media and supplements free of bovine components. Furthermore, it is also important to remove the feeder layer, because it is prepared with genetically transformed animal cells. Although antigenic or tumorigenic effects by the use of these cells in patients treated with cultured epidermis have not be reported, these risks should never be completely discarded.

\section{How Is Epidermis Grown in Vitro?}

The epidermis, from ectodermic origin, contains three different types of keratinocytes: epidermal stem cells, capable of infinite rounds of cell division; their immediate descendants, the transient amplifying cells, capable of many but finite rounds of division; and finally, the differentiated cells, that are not able to divide [35]. All these cell types are present in the skin sample to be cultured.

The epidermis culture technique starts by taking a biopsy of skin, containing dermis and epidermis, following a strict and careful protocol for the antisepsis of the donor site, in order to avoid the contamination of the sample.

The skin is enzymatically digested in order to separate dermis from epidermis (Figure 2). The latter is subjected to another digestion to obtain a suspension of keratinocytes that includes cells from all the epidermal layers. This suspension contains all cells, from the basal to the most differentiated cells of stratum corneum. Only a small fraction of the keratinocytes of epidermis (between $1 \%$ and 5\%) has proliferation capacity. These cells are those that allow for the in vitro epidermis culture to be carried forward.

Keratinocytes are seeded on flasks/plates, where only those basal cells have the ability to adhere, migrate and proliferate (Figure 3(a)). This is the proliferation phase, in which cells proliferate to cover the entire the plastic surface, remaining as undifferentiated cells.

During this stage, the cells are amplified depending on the amount of surface that needs to be covered.

After the amplification, the cells reach confluence (Figure 3(b)). At this point, the cell-cell contact, coupled

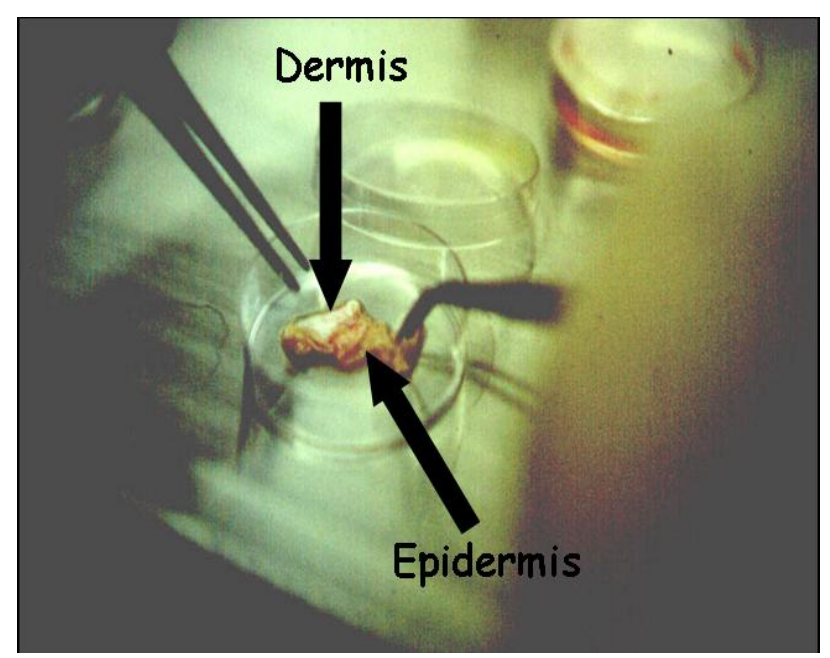

Figure 2. The separation of dermis and epidermis after enzymatic digestion. 


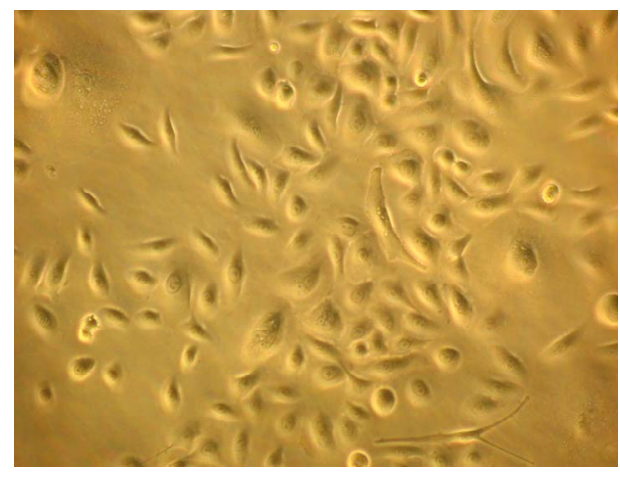

(a)

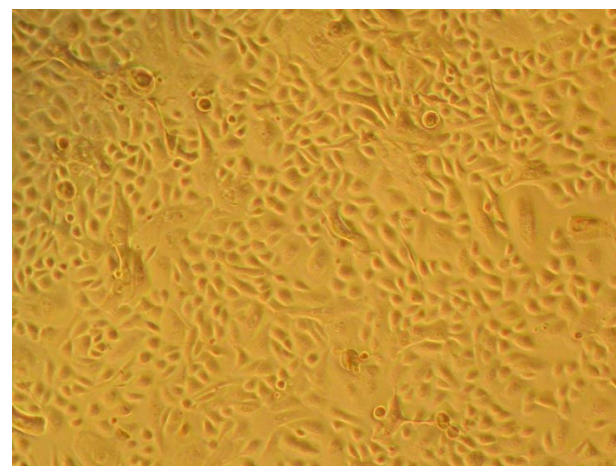

(b)

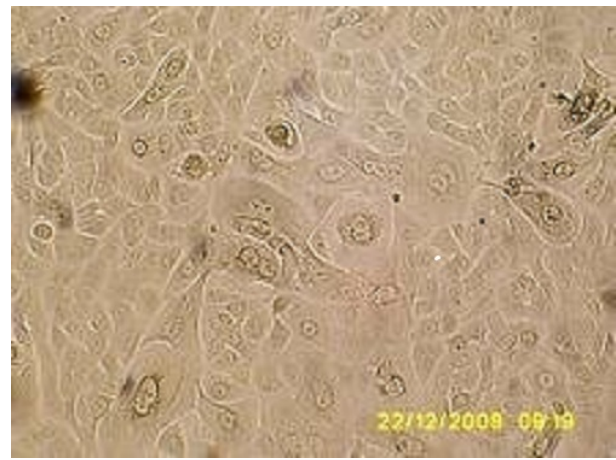

(c)

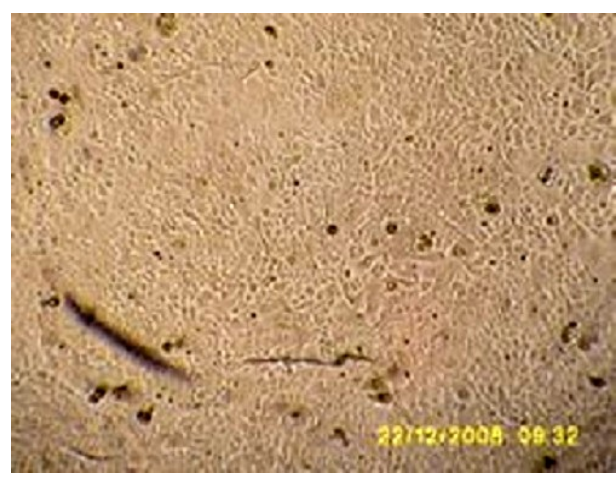

(d)

Figure 3. Bright field micrographs of in vitro keratinocyte cultures, taken from Axiovert Carl Zeiss inverted microscope. (a) Seven day-culture $(800 \times)$; (b) Thirteen day-culture (450×); (c) Twenty day-culture (450×); (d) Twenty four dayculture $(350 \times)$. to the stimulation produced by variations in the concentrations of ions $\mathrm{Ca}^{++}$in the culture medium, stimulates the keratinocytes differentiation (Figure 3(c)) and stratification, finally forming an epidermal stratified sheet (Figure 3(d)).

At this point the epidermal sheets are harvested by enzymatic treatment, then are placed on Vaseline gauze (Figure 4), and are transported to the operating room, where they are applied on wounds (Figure 5), and protected with a mesh (Figure 6). Pictures 2, 4, 5 and 6 were taken from burn patients treated by Dr. Fortunato Benaim, during his clinical practice. Cultured epidermis was performed in the Skin Culture Laboratory belonging to Fundación del Quemado Dr. F. Benaim, in Buenos Aires, Argentina.

Histological analysis of cultured epidermal sheet, immediately after being harvested, show a row of large cells, spherical in shape, with high nucleus/cytoplasm ratio, corresponding to the basal layer. Likewise, there were three to four layers of cells displaying elongated shapes and small sizes. In the outermost layer, the nuclei were smaller or absent (Lorenti A, unpublished data).

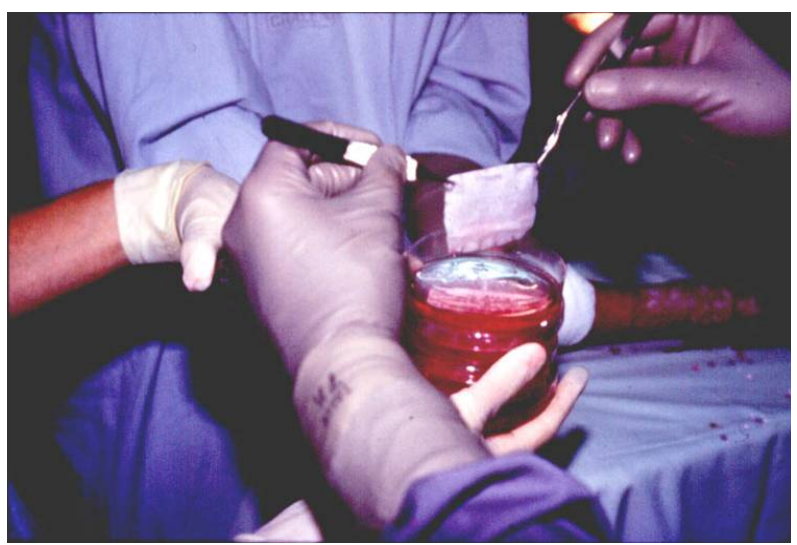

Figure 4. Harvesting cultured epidermis sheets and placing on Vaseline gauze.

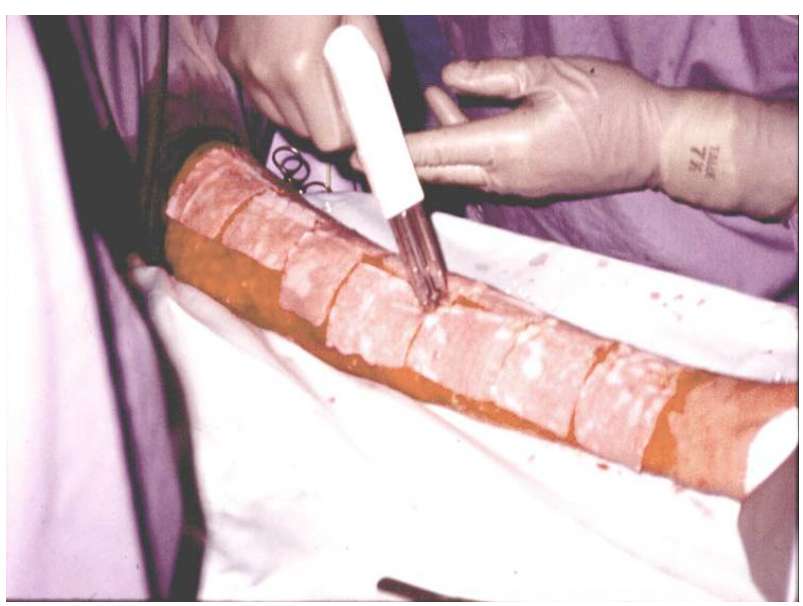

Figure 5. Placement of cultured epidermis sheets on wounds. 
Analized by electron microscopy, the epidermal sheet revealed the presence of desmosome-like junctions, mitochondria and glycogen granules (Figures 7(a) and (b)).

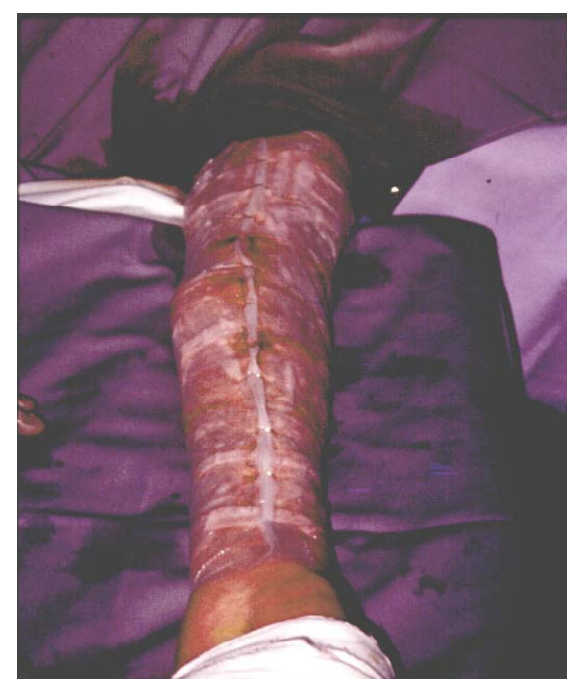

Figure 6. Protection of the epidermis sheets with a mesh.

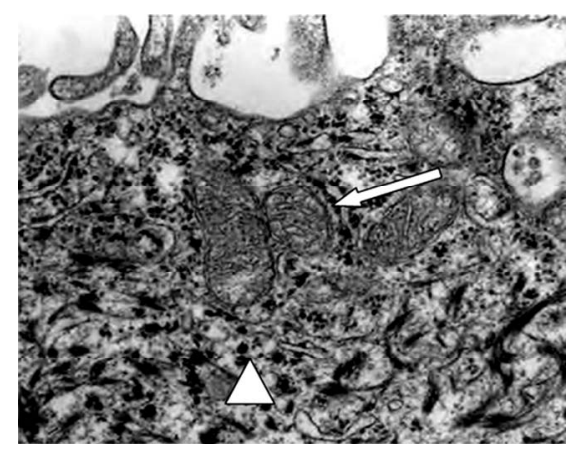

(a)

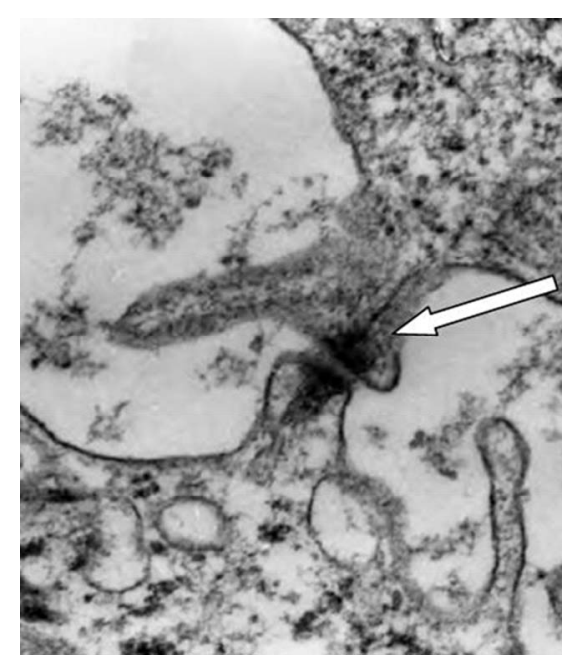

(b)

Figure 7. Electron microscopy of cultured epidermal sheet, immediately after being harvested. (a) Mitochondria (white arrow) and glycogen granules (white triangle); (b) Desmosome-like junctions (white arrow) $(20,000 \times)$.

\section{Clinical Use of Cultured Epidermis}

The therapeutic potential of epidermis culturing was started after the works of Rheinwald and Green. O’Connors et al. first used cultured autologous epidermis in two adult patients with extensive and deep burns [14]. In these patients, cultured epidermis sheets were placed on wound beds with granulated tissue. Approximately 50\% of these sheets had grafted properly, but infections were the leading causes of loss. In areas where the cultured sheets were successfully grafted, healing was achieved and there was no evidence of increased weakness or greater contraction than those areas treated with traditional autografts. The cultured autografts were stable even three years after placement.

Later, the same authors used cultured epidermis for the treatment of paediatric patients. In this group of patients, the wounds were excised early to the level of the fascia or subcutaneous tissue, and temporarily covered with homograft from skin banks, until the cultured autologous epidermis was ready to be grafted. Early excision of burned areas and their immediate coverage reduces the risk of complications, as mentioned above, and therefore the risk of infections also decrease. This allowed a better engraftment of cultured epidermis that reached $70 \%$ $80 \%$. The authors emphasize the importance of a proper bed preparation, on the outcome $[15,36]$. From that time, many burn centres in the world adopted this technology for the treatment of patients [34,37-47].

The histology of cultured epidermis grafted in patients with deep burns was analyzed. Samples were taken at 9 days, 6 weeks and 5 to 21 months post-graft. In the sixth week after transplantation, the cultured epithelium consisted of 10 to 20 cell layers that showed a complete maturation, with the presence of basal, spinous, granular and corneal layers. After 5 months, completely normal structure was showed, with basal cells containing keratohyalin granules, desmosomes and basement membrane [48].

From the experience that was gained from using cultured epidermis in burn patients, this technology was also used as post-resection coverage of giant congenital nevi [49], for chronic ulcers of various etiologies [50], and epidermolysis bullosa [51], among others.

\section{Clinical Experience in Argentina}

Epidermis cultured has also been used in Argentina, for the treatment of burn patients. This practice began in 1991, when an epidermis culturing laboratory was created at Fundación del Quemado Dr. Fortunato Benaim [52-54]. Many patients, both adults and paediatrics, were treated, with similar results to other international working groups. 


\section{Tissue Engineering and Cutaneous Substitutes}

Although, as already mentioned, a considerable number of patients were successfully treated with in vitro cultured epidermis, in many other patients, success was only partial. This is mainly due to the weakness of cultured epidermis sheet, which is very susceptible to infections, as well as to the frictions generated by the actions associated with the routine treatments of these patients. The fundamental cause is, undoubtedly, the absence of dermal support for the epidermal sheet.

That is why the evolution of techniques began to move towards the search for tools which would improve the substitute. This can be addressed in two ways: either the bed is prepared with a dermal equivalent that can vascularise, and provide a basis for the cultured epidermal sheet, or creating substitutes, in vitro, containing both layers of the skin [55].

In any case, the dermal substitute should allow correct and permanent adhesion of epidermal cells, and the formation of a new vasculature, to reach efficient wound healing [38].

Will be discussed below these two options: first, the preparation of the wound bed with a dermal equivalent, allowing vascularisation, and then placement of cultured epidermal sheet on it; or second, the creation of bilayer substitutes, dermal-epidermal, all in vitro.

\subsection{Dermal Equivalents Used as Base for Cultured Epidermal Sheets}

The chemical composition, and the structure of the substitute, significantly impacts the biologic response of epithetlial cells after grafting, and also modulate the processes involved in epidermal differentiation and wound healing, trying to restore the normal structure and function of the skin [56]. In many cases, excessive wound contraction and scar formation may create severe functional and cosmetic defects.

Progress in understanding molecular biology and tissue engineering has produced significant advances in the development of skin substitutes, particularly in relation to the dynamics of cell-extracellular matrix interactions that, as mentioned above, is critical to the successful graft of the substitute [57].

Biomaterials developed with matrix proteins, used as dermal substitutes, favours cell repopulation and revascularisation [58]. Some of them are capable of sustaining the growth of both, keratinocytes and fibroblasts, resulting in a dermal-epidermal composite structure, and achieving a complete and functional regeneration of damaged skin [55].

One of the first attempts to develop a biologic substitute was made by Burke et al., who developed the so- called artificial skin (Integra ${ }^{\circledR}$ ), made with a type I collagen sponge plus glycosaminglycanes, and covered with a silicone sheet (Sylastic) acting as temporary barrier. This structure is placed on the wound bed and, after vascularisation, the silicone sheet could be replaced with a partial-thickness autograft or with a sheet of cultured autologous keratinocyte sheet [59-62].

Cadaver skin obtained from multiorgan donors, and processed in skin banks, has been used for many years as temporary coverage of patients with extensive and deep burns. Several cadavers skin banks exist in Argentina [63].

Cuono and colleagues have expanded the possible uses of homologous skin, by using this not as temporary covering, but as a permanent dermal substitute $[38,39]$. For this purpose, the burned tissue is excised early, and the wound bed is covered immediately with homologous skin from skin banks, and after 7 - 10 days the homoepidermis is removed. The homologous dermis, that does not undergo immune rejection, can vascularise and then serve as a bed for placing thereon the sheets of cultured autologous keratinocytes. This technique has also been used in Argentina [64].

\subsection{Development of in Vitro Dermal-Epidermal Bilayer Substitutes}

In order to avoid the laborious process of harvesting epidermal sheets, it is possible to seed the keratinocytes on biologic membranes in vitro, allowing cell adhesion to this membrane, and for the implantation of this assembly on the wounds. The final stage of differentiation and stratification will occurs in vivo, shortening the cultivation time.

The use of scaffolds allows the development of dermalepidermal substitutes, which not only contains keratinocytes, but also fibroblasts. The latter are mesenchymal cells that can be grown in the laboratory, and play significant role in epithelial-mesenchymal interactions, by secreting various growth factors and cytokines. This has direct effects on the proliferation of epidermal cells and the synthesis of extracellular matrix [65]. The addition of fibroblasts has been a key factor in the development of substitutes dermal-epidermal, through tissue engineering techniques.

Lindberg et al. observed a growth pattern of human epidermal cells, cultured on an extracellular matrix derived from intestinal submucosa. The authors observed differentiation markers such as keratins 10, 14 and 16, fibronectine, laminine, and collagens type VII and IV. The authors also have co-cultured both keratinocytes and dermal fibroblasts, seeded on the opposite sides of the matrix, observing the coexistence of the two cell types, as well as cell migration, proliferation and differentiation, indicating their potential application as dermal-epidermal 
substitutes [66].

A similar scaffold is a matrix derived from porcine bladder submucose, described by Badylak et al. The authors describe the capacity of adhesion, migration, proliferation, and differentiation of epidermal and dermal cells and also the release of basal membrane components. This emphasizes the usefulness of this model to study cell-matrix interactions for the development of dermoepidermal substitutes [67].

Boyce and colleagues noted a rapid and effective closure of deep wounds in 40 burn patients, using autologous cultures of keratinocytes and fibroblasts, placed on a collagen sponge, and compared with wounds treated with traditional autografts. They demonstrated that the use of cultured grafts significantly reduces the requirements of donor areas, reducing the healing time, morbidity and mortality in these patients [68].

The usefulness of skin processed in skin banks can not only be used as a base upon which to place the cultured epidermal sheet, but also as scaffold for the in vitro culture of both autologous fibroblasts and keratinocytes. This scaffold, which contains epidermal and dermal native structures, allows the development of a total skin replacement [69].

\section{Homologous Cells for the Development of Skin Substitutes}

Until now, the cultivation of epithelial cells has been discussed only for autologous use. However, cultured keratinocytes and fibroblasts can also be used for allogeneic transplantation. Homologous (allogeneic) cells are generally derived from neonatal foreskin from circumcision. The primary functions of these cells are to provide growth factors that stimulate the healing of wounds in the recipient patient [70]. In a multicenter study, intermediate burns were treated with cultured homologous epidermis. The results showed that the cells found in the healed wounds were cells of the recipient, and not of the donor [47].

Dermagraft ${ }^{\circledR}$ is one example of this. It is a membrane of polyglycolic acid on a three-dimensional mesh of nylon, containing homologous fibroblasts [71,72].

Another example is Apligraft ${ }^{\circledR}$, which is a bilayer structure, with a bottom layer of type I collagen containing homologous cultured fibroblasts. Homologous keratinocytes are seeded and cultivated, and placed on this structure until the formation of stratum corneum, and then placed on the wounds [73].

The treatment of intermediate [74-77] and deep burns [78] is one example of the clinical application of cultured, homologous epidermis. When it was applied on patients with ulcers of various aetiologies in a clinical trial by Phillips T. et al., patients experienced less pain and faster epithelisation when applied on venous ulcers, and poorer results in deep ulcers and those derived from connective tissue diseases [79].

The possibility of using cultured, homologous epidermis is particularly attractive from the practical point of view, because the cultured cells are prepared in vitro and then cryopreserved and stored, and are available for use when needed, omitting the time required for autologous culturing.

\section{Epidermal Stem Cells for the Development of Skin Substitutes}

As already mentioned, dermis and epidermis have different origins. They are adjacent and interdependent but differ significantly in their organization and cellular components. In the epidermis, as in other adult organs with high renewal rate, there are specific mechanisms to allow for cell replacement during the processes of homeostasis and healing. Stem cells regulate these processes in adult tissues because they have high self-renewal capacity, the ability to produce undifferentiated progenies throughout the whole lifetime of the individual, and the ability to differentiate into different functional cell types. Thus, the integrity of the epidermis is maintained by the presence of stem cells, which carry out the tissue homeostasis and regeneration. These cells, that are normally quiescent, are activated in particular situations, such as the entry of hair follicles in the last period of their cycle (catagen), or in the process of re-epithelisation during wound healing events after epithelial injury [8083].

Stem cells are located in specific niches characteristic to each organ. These cells are intimately associated with their niche for maintenance and function. A niche consists of a microenvironment capable of housing and maintaining one or more stem cells. It is not merely a place of residence for stem cells, but a fundamental concept that involves not only stem cells, but also the neighbouring progenitor cells and all the interactions between them. The niche represents a defined anatomical compartment that provides signals to stem cells in the form of secreted and cell surface-adhered molecules to control the fate of stem cells. This fate could be proliferation, self-renewal, differentiation, apoptosis, adhesion, or migration [84].

The niche concept is fundamental in the biology of stem cells. A cell is considered a stem cell only when it is interacting in its niche. This has led to conclude that the stemness is a condition rather a cellular entity, and that the stem cell can go in and out of the stem cell condition, depending on the signals they are receiving [85].

In the epidermis, the niche of stem cells is located in a reservoir (bulge) in the hair follicle. These are the cells that respond to the process of degeneration of the hair follicle (catagen), interacting with the dermal papilla, 
producing a new follicle. On the other hand, when an epithelial damage occurs, the same stem cells receive different signals than the aforementioned, and they respond to those signals by promoting the migration of stem cells from the reservoir towards the basal lamina to repair the damage. This is a clear example of a population of stem cells located in its niche, which respond differently depending on the stimulus they receive. The microenvironment surrounding the epidermal stem cells is responsible of generating the stimuli that regulate cellular proliferation and differentiation [86,87].

To start growing the epidermis in vitro, the entire population of cells from the epidermis sample is used. This sample contains only a few epidermal stem cells. The hair follicle contains a greater number of stem cells and therefore is considered an attractive source of those cells for tissue engineering [88].

Tausche A. et al. developed an epidermal autologous equivalent, for patients with vascular ulcers, by using tissue engineering. Keratinocytes were isolated from the root of hair follicles, and grown organotypically in vitro. The epidermal equivalent was used in a multicenter phase II clinical trial, showing an effective stimulation of healing of the partial thickness areas, and completes closure of the ulcers [88-91].

\section{Conclusions}

Wound healing is a complex process involving dermal and epidermal cells, extracellular matrix components, and a sum of signals emanating from the wound and the healthy tissue around it. Therefore, the ideal replacement would be one that is able to establish itself and to survive, as well as to promote the migration of the resident cells toward the wound, collaborate and accelerate the healing process. The extracellular matrix plays an essential role in the healing process, providing the physical, biological and chemical keys guiding cell function.

A critical aspect to consider is the translation of skin replacement from bench to bedside while maintaining the ultimate goal of meeting patient needs through these developing technologies.

Tissue engineering is moving ahead thanks to the understanding of the dynamic relationship between cells, extracellular matrix, and bioactive factors. As an emerging technology, tissue engineering holds the promise of new approaches for repair of damaged tissues, combining the advances in cell culture techniques with progresses in the development of biomaterials.

The tissue engineered skin and its therapeutic applications reported in this review demonstrate the feasibility and effectiveness of these approaches. It represents a clear benefit in wound healing, particularly for extensive and deep burns and long-standing ulcers. Now, focus must be directed on the development of new scaffolds, developed by different technologies, such as polymer science, or nanotechnology, able to be used as templates to direct the growth of cells, in an attempt to better regenerate the lost skin [92,93].

\section{Acknowledgements}

To Dr. Fortunato Benaim, for his critical reading of this manuscript, as well as his permanent enthusiasm, encouragement and support. To Dr. Alejandra Depetris for her valuable help in the correction of this manuscript.

\section{REFERENCES}

[1] B. Pomahac, T. Svensjo, F. Yao, H. Brown and E. Ericksson, "Tissue Engineering of Skin," Critical Reviews in Oral Biology \& Medicine, Vol. 9, No. 3, 1998, pp. 333-344. doi:10.1177/10454411980090030601

[2] J. Fisher, "Skin: The Ultimate Solution for the Burn Wound," The New England Journal of Medicine, Vol. 311, 1984, pp. 466-467. doi:10.1056/NEJM198408163110711

[3] C. Charles, P. Romanelli, Z. Martinez, F. Ma, B. Roberts and R. Kirsner, "Tumor Necrosis Factor-Alfa in Nonhealing Venous Leg Ulcers," Journal of the American Academy of Dermatology, Vol. 60, No. 6, 2009, pp. 951955. doi:10.1016/j.jaad.2008.09.012

[4] J. Stechmiller, L. Cowan and G. Schultz, "The Role of Doxycycline as a Matrix Metalloproteinase Inhibitor for the Treatment of Chronic Wounds," Biological Research for Nursing, Vol. 11, No. 4, 2010, pp. 336-344. doi:10.1177/1099800409346333

[5] D. Herndon and D. Parks, "Comparison of Serial Debridement and Autografting and Early Massive Excision with Cadaver Skin Overlay in the Treatment of Large Burns in Children,” Journal of Trauma-Injury Infection \& Critical Care, Vol. 26, No. 2, 1986, pp. 149-152. doi:10.1097/00005373-198602000-00009

[6] G. Colocho, W. Graham, A. Greene, D. Matheson and D. Lynch, "Human Amniotic Membrane as a Physiologic Wound Dressing," Archives of Surgery, Vol. 109, No. 3, 1974, pp. 370-373.

doi:10.1001/archsurg.1974.01360030022006

[7] S. Sakiel and J. Grzybowski, "Clinical Application of New Bovine Collagen Membranes as a Partial-Thickness Burn Wound Dressing,” Polimery w Medycynie, Vol. 25, No. 3-4, 1995, pp. 19-24.

[8] T. Maral, H. Borman, H. Arslan, B. Demirhan, G. Akinbingol and M. Haberal, "Efectiveness of Human Amnion Preserved Long-Term in Glycerol as a Temporary Biological Dressing,” Burns, Vol. 25, No. 7, 1999, pp. 625635. doi:10.1016/S0305-4179(99)00072-8

[9] H. Ehrlich, "Understanding Experimental Biology of Skin Equivalent: From Laboratory to Clinical Use in Patients with Burns and Chronic Wounds,” The American Journal of Surgery, Vol. 187, No. 5A, 2004, pp. 29S-33S. doi:10.1016/S0002-9610(03)00301-5

[10] R. Singh and M. Chacharkar, "Dried Gamma-Irradiated 
Amniotic Membrane as Dressing in Burn Wound Care," Journal of Tissue Viability, Vol. 20, No. 2, 2011, pp. 4954. doi:10.1016/j.jtv.2010.06.001

[11] J. Rheinwald and H. Green, "Formation of Keratinizing Epithelium in Culture by a Cloned Cell Line Derived from a Teratoma," Cell, Vol. 6, No. 3, 1975, pp. 317-330. doi:10.1016/0092-8674(75)90183-X

[12] J. Rheinwald and H. Green, "Serial Cultivation of Strains of Human Epidermal Keratinocytes: The Formation of Keratinizing Colonies From Single Cells,” Cell, Vol. 6, No. 3, 1975, pp. 331-344. doi:10.1016/S0092-8674(75)80001-8

[13] J. Rheinwald and H. Green, "Epidermal Growth Factor and the Multiplication of Cultured Human Epidermal Keratinocytes," Nature, Vol. 265, No. 5593, 1977, pp. 421424.

[14] N. O’Connors, J. Mulliken, S. Banks-Schlegel, O. Kehinde and H. Green, "Grafting of Burns with Cultured Epithelium from Autologous Epidermal Cells," Lancet, Vol. 317, No. 8211, 1981, pp. 75-78. doi:10.1016/S0140-6736(81)90006-4

[15] N. O’Connor, G. Gallico, C. Compton, O. Kehinde and H. Green, "Grafting Burns with Cultured Epithelium Prepared from Autologous Epidermal Cells. II: Intermediate Results on Three Pediatric Patients," In: T. Hunt, R. Heppenstall, E. Pines and D. Rovee, Eds., Soft and Hard Tissue Repair: Biological and Clinical Aspects, Praeger Scientific, New York, 1984, pp. 283-292.

[16] W. Eaglstein, M. Iriondo and K. Laszlo, “A Composite Skin Substitute (Graftskin) for Surgical Wounds: A Clinical Experience,” Dermatologic Surgery, Vol. 21, No. 10, 1995, pp. 839-843. doi:10.1016/1076-0512(94)00290-8

[17] R. Langer and J. Vacanti, "Tissue Engineering," Science, Vol. 260, No. 5110, 1993, pp. 920-926. doi:10.1126/science.8493529

[18] J. Vacanti and C. Vacanti, "The Challenge of Tissue Engineering,” In: R. Lanza, R. Langer and W. Chick, Eds., Principles of Tissue Engineering, Academic Press, Inc., Cambridge,1997, pp. 1-5.

[19] C. Erickson, “Organization of Cells into Higher Ordered Structures: The Role of the Epithelial-Mesenchymal Transformation in the Generation and Stabilization of Embryonic Tissues,” In: R. Lanza, R. Langer and W. Chick, Eds., Principles of Tissue Engineering, Academic Press, Inc., Cambridge, 1997, pp. 9-22.

[20] E. Hill, T. Boontheekul and D. Mooney, "Regulating Activation of Transplanted Cells Controls Tissue Regeneration," Proceedings of the National Academy of Sciences, Vol. 103, No. 8, 2006, pp. 2494-2499. doi:10.1073/pnas.0506004103

[21] K. Hellman and R. Nerem, “Advancing Tissue Engineering and Regenerative Medicine,” Tissue Engineering, Vol. 13, No. 12, 2007, p. 2823. doi:10.1089/ten.2007.1504

[22] S. Sart, A. Errachid, Y. Schneider and S. Agathos, "Modulation of Mesenchymal Stem Cell Actin Organization on Conventional Microcarriers for Proliferation and Differ- entiation in Stirred Bioreactors,” Journal of Tissue Engineering and Regenerative Medicine, 2012 (Epub Ahead of Print). doi:10.1002/term.545

[23] S. Ziane, S. Schlaubitz, S. Miraux, A. Patwa, C. Lalande, I. Bilem, et al., "A Thermosensitive Low Molecular Weight Hydrogel as Scaffold for Tissue Engineering," European Cells and Materials, Vol. 23, 2012, pp. 147160.

[24] A. Lorenti, A. Hidalgo, M. Barbich, J. Torres, J. Batalle, M. F. Izaguirre, et al., "Structural and Functional Polarity of Porcine Hepatocyte Cultured Spheroids," Acta Gastroenterológica Latinoamericana, Vol. 36, No. 2, 2006, pp. 66-75.

[25] V. Spotorno, A. Hidalgo, M. Barbich, A. Lorenti and O. Zabal, "Culture of Bovine Hepatocytes: A Non-Perfusion Technique for Cell Isolation,” Cytotechnology, Vol. 51, No. 2, 2006, pp. 51-56. doi:10.1007/s10616-006-9000-0

[26] A. Lorenti, "Ingeniería Tisular: Generación in Vitro De Organoides Hepáticos,” In: Medicina Regenerativa y Stem Cells, Universidad Nacional de Quilmes, Quilmes, 2005, pp. 113-140.

[27] A. Lorenti, M. Barbich, M. de Santibáñes, M. Ielpi, J. C. Vazquez, P. Sorroche, et al., "Ammonium Detoxification Performed by Porcine Hepatocyte Spheroids in a Bioartificial Liver for Pediatric Use: Preliminary Report,” Artificial Organs, Vol. 27, No. 7, 2003, pp. 665-670. doi:10.1046/j.1525-1594.2003.07098.x

[28] C. Ramirez, "Matrices y Biomateriales en Ingeniería de Tejidos,” In: Medicina Regenerativa y Stem Cells. De la Terapia Celular a la Ingeniería de Tejidos, Universidad Nacional de Quilmes, Quilmes, 2005, pp. 141-174.

[29] E. Alsberg, H. von Recum and M. Mahoney, “Environmental Cues to Guide Stem Cell Fate Decision for Tissue Engineering Applications,” Expert Opinion on Biological Therapy, Vol. 6, No. 9, 2006, pp. 847-866. doi:10.1517/14712598.6.9.847

[30] D. Ingber, "Mechanochemical Switching between Growth and Differentiation by Extracellular Matrix,” In: R. Lanza, R. Langer and W. Chick, Eds., Principles of Tissue Engineering, Academic Press Inc., Cambridge, 1997, pp. 89100.

[31] M. Parshley and H. Simms, "Cultivation of Adult Skin Epithelial Cells (Chicken and Human) in Vitro,” Journal of Anatomy, Vol. 86, No. 2, 1950, pp. 163-189. doi:10.1002/aja.1000860202

[32] B. Flaxman, M. Lutzner and E. Van Scott, "Ultrastructure of Cell Attachment to Substratum in Vitro," The Journal of Cell Biology, Vol. 36, No. 2, 1968, pp. 406-410. doi:10.1083/jcb.36.2.406

[33] M. Karasek, "Growth and Differentiation of Transplanted Epithelial Cell Cultures,” Journal of Investigative Dermatology, Vol. 51, 1968, pp. 247-252.

[34] M. Pittelkow and R. Scott, "New Techniques for the in Vitro Culture of Human Keratinocytes and Perspectives on Their Use for Grafting Patients with Extensive Burns," Mayo Clinic Proceedings, Vol. 61, No. 10, 1986, pp. 771777.

[35] D. Aberdam, “Epidermal Stem Cell Fate: What Can We 
Learn from Embryonic Stem Cells?” Cell and Tissue Research, Vol. 331, No. 1, 2008, pp. 103-107. doi:10.1007/s00441-007-0497-0

[36] G. Gallico, N. O’Connor, C. Compton, O. Kehinde and H. Green, "Permanent Coverage of Large Burn Wounds with Autologous Cultured Human Epithelium,” The New England Journal of Medicine, Vol. 311, 1984, pp. 448-451. doi:10.1056/NEJM198408163110706

[37] R. Teepe, R. Kreiss, E. Koebrugge, J. Kempenaar, A. Vloemans, R. Hermans, et al., "The Use of Cultured Autologous Epidermis in the Treatment of Extensive Burn Wounds," The Journal of Trauma and Acute Care Surgery, Vol. 30, No. 3, 1990, pp. 269-275. doi:10.1097/00005373-199003000-00004

[38] C. Cuono, R. Langdon and J. McGuire, "Use of Cultured Epidermal Autografts and Dermal Allografts as Skin Replacement after Burn Injury,” Lancet, Vol. 1, No. 8490, 1986, pp. 1123-1124. doi:10.1016/S0140-6736(86)91838-6

[39] C. Cuono, R. Langdon, N. Birchall, S. Bartelbort and J. McGuire, "Composite Autologous-Allogeneic Skin Replacement: Development and Clinical Application,” Plastic and Reconstructive Surgery, Vol. 80, No. 4, 1987, pp. 626-635. doi:10.1097/00006534-198710000-00029

[40] A. Eldad, A. Burt and J. Clarke, "Cultured Epithelium as a Skin Substitute,” Burns, Vol. 13, No. 3, 1987, pp. 173180. doi:10.1016/0305-4179(87)90161-6

[41] J. Latarjet, M. Gangolphe, G. Hezez, C. Masson, J. Cognet, J. Galoisy, et al., "The Grafting of Burns with Cultured Epidermis as Autografts in Man," Scandinavian Journal of Plastic and Reconstructive Surgery and Hand Surgery, Vol. 21, No. 3, 1987, pp. 241-244. doi:10.3109/02844318709086450

[42] M. Faure, G. Mauduit, D. Schmitt, J. Kanitakis, A. Demidem and J. Thivolet, "Growth and Differentiation of Human Epidermal Cultures Used as Auto- and Allografts in Humans," British Journal of Dermatology, Vol. 116, No. 2, 1987, pp. 161-170. doi:10.1111/j.1365-2133.1987.tb05807.x

[43] M. Kumagai, H. Nishina, H. Tanabe, T. Hosaka, H. Ishida and Y. Ogino, "Clinical Application of Autologous Cultured Epithelia for the Treatment of Burn Wounds and Burn Wound Scars," Plastic and Reconstructive Surgery, Vol. 82, No. 1, 1988, pp. 99-108.

[44] J. Hunyadi, F. Farkas, G. Bertenyi, J. Olah and A. Dobozy, "Keratinocyte Grafting: A New Means of Transplantation for Full-Thickness Wounds," Journal of Dermatologic Surgery \& Oncology, Vol. 14, No. 1, 1988, pp. 75-78.

[45] S. Herzog, A. Meyer, D. Woodley and H. Peterson, "Wound Coverage with Cultured Autologous Keratinocytes: Use after Burn Wound Excision, Including Biopsy Follow-Up," The Journal of Trauma and Acute Care Surgery, Vol. 28, No. 2, 1988, pp. 195-198. doi:10.1097/00005373-198802000-00011

[46] J. Aubock, E. Irschick, N. Romani, P. Kompatscher, R. Höpfl, M. Herold, et al., "Rejection, after a Slightly Prolonged Survival Time, of Langerhans Cell-Free Allogeneic Cultured Epidermis Used for Wound Coverage in
Humans,” Transplantation, Vol. 45, No. 4, 1988, pp. 730737. doi:10.1097/00007890-198804000-00013

[47] M. De Luca, S. Bondanza, R. Cancedda, A. Tamisani, C. Di Noto, L. Muller, et al., "Permanent Coverage of Full Skin Thickness Burns with Autologous Cultured Epidermis and Re-Epithelialization of Partial Skin Thickness Lesions Induced by Allogeneic Cultured Epidermis: A Multicentre Study in the Treatment of Children,” Burns, Vol. 18, Suppl. 1, 1998, pp. S16-S19.

[48] M. Aihara, "Ultrastructural Study of Grafted Autologous Cultured Human Epithelium,” British Journal of Plastic Surgery, Vol. 42, No. 1, 1989, pp. 35-42.

[49] G. Gallico, N. O’Connor, C. Compton, J. Remensnyder, O. Kehinde and H. Green, "Cultured Epithelial Autografts for Giant Congenital Nevi," Plastic and Reconstructive Surgery, Vol. 84, No. 1, 1989, pp. 1-9. doi:10.1097/00006534-198907000-00001

[50] J. Hefton, D. Caldwell, D. Biozes, D. Carter, et al., "Grafting of Skin Ulcers with Cultured Autologous Epidermal Cells," Journal of the American Academy of Dermatology, Vol. 14, No. 3, 1986, pp. 399-405. doi:10.1016/S0190-9622(86)70048-0

[51] D. Carter, A. Lin, M. Varghese, D. Caldwell, L. Pratt and M. Eisinger, "Treatment of Junctional Epidermolysis Bullosa with Epidermal Autografts," Journal of the American Academy of Dermatology, Vol. 17, No. 2, 1987, pp. 246250. doi:10.1016/S0190-9622(87)70199-6

[52] A. Lorenti, “Cultivo de Epidermis,” Revista Argentina de Quemaduras, Vol. 6, 1991, pp. 20-21.

[53] A. Lorenti and F. Benaim, "Uso de Vancomicina en Forma Local en un Paciente Quemado Grave Tratado con Epidermis Cultivada in Vitro,” Revista de la Asociación Médica Argentina, Vol. 105, 1992, pp. 1-7.

[54] A. Lorenti, "Cultivo de Epidermis. Primeras Experiencias en el Laboratorio de la Fundación del Quemado Dr. Fortunato Benaim,” Revista Argentina de Quemaduras, Vol. 7, 1993, pp. 1-2.

[55] Y. Bello, A. Falabella and W. Eaglstein, "Tissue-Engineered Skin. Current Status in Wound Healing," American Journal of Clinical Dermatology, Vol. 2, No. 5, 2001, pp. 305-313. doi:10.2165/00128071-200102050-00005

[56] C. Compton, W. Hickerson, K. Nadire and W. Press, "Acceleration of Skin Regeneration from Cultured Epithelial Autografts by Transplantation to Homografts Dermis,” Journal of Burn Care \& Rehabilitation, Vol. 14, No. 6, 1993, pp. 653-662.

doi:10.1097/00004630-199311000-00010

[57] A. D. Widgerow, "Bioengineered Matrices-Part 1: Attaining Structural Success in Biologic Skin Substitutes," Annals of Plastic Surgery, Vol. 68, No. 6, 2012, pp. 568573. doi:10.1097/SAP.0b013e31824b3d04

[58] S. MacNeil, "Progress and Opportunities for Tissue-EngiNeered Skin,” Nature, Vol. 445, No. 7130, 2007, pp. 874880. doi:10.1038/nature05664

[59] R. Stern, M. McPherson and M. Longaker, "Histologic Study of Artificial Skin Used in the Treatment of Full Thickness Thermal Injury,” Journal of Burn Care \& Rehabilitation, Vol. 11, No. 1, 1990, pp. 7-13. 
doi:10.1097/00004630-199001000-00003

[60] S. Boyce, R. Kagan, N. Meyer, K. Yakuboff and G. Warden, "Cultured Skin Substitutes Combined with Integra Artificial Skin to Replace Native Skin Autograft and Allograft for Closure of Full Thickness Burns,” Journal of Burn Care \& Rehabilitation, Vol. 20, No. 6, 1999, pp. 453-461. doi:10.1097/00004630-199920060-00006

[61] S. Boyce, R. Kagan, K. Yakuboff, N. Meyer, M. Rieman, D. Greenhalgh, et al., "Cultured Skin Substitutes Reduce Donor Skin Harvesting for Closure of Excised, FullThickness Burns," Annals of Surgery, Vol. 235, No. 2, 2002, pp. 269-279. doi:10.1097/00000658-200202000-00016

[62] D. M. Supp and S. T. Boyce, "Engineered Skin Substitutes: Practices and Potentials," Clinics in Dermatology, Vol. 23, No. 4, 2005, pp. 403-412. doi:10.1016/j.clindermatol.2004.07.023

[63] A. Lorenti, A. Bolgiani and F. Benaim, "Modificación de los Protocolos de trabajo del Banco de Piel de la Fundación Benaim,” Revista Argentina de Quemaduras, Vol. 10, 1995, pp. 22-23.

[64] C. Perroni, A. Rodríguez, D. Rosset, L. Barba, A. Lorenti and F. Benaim, "Uso de Tratamiento Combinado de Epidermis Cultivada con Homodermis Irradiada Como Base, en un Paciente Quemado Crítico,” Revista Argentina de Quemaduras, Vol. 11, 1996, pp. 24-28.

[65] T. Wong, J. McGrath and H. Navsaria, "The Role of Fibroblasts in Tissue Engineering and Regeneration,” British Journal of Dermatology, Vol. 156, No. 6, 2007, pp. 1149-1155. doi:10.1111/j.1365-2133.2007.07914.x

[66] K. Lindberg and S. Badylak, "Porcine Small Intestinal Submucosa (SIS): A Bioscaffold Supporting in Vitro Primary Human Epidermal Cell Differentiation and Synthesis of Basement Membrane Proteins,” Burns, Vol. 27, No. 3, 2001, pp. 254-266. doi:10.1016/S0305-4179(00)00113-3

[67] S. Badylak, D. Freytes and T. Gilbert, "Extracellular Matrix as a Biological Scaffold Material: Structure and Function,” Acta Biomaterialia, Vol. 5, No. 1, 2009, pp. 1-13. doi:10.1016/j.actbio.2008.09.013

[68] ] S. Boyce, R. Kagan, D. Greenhalgh, P. Warner, K. Yakuboff, T. Palmieri, et al., "Cultured Skin Substitutes Reduce Requirements for Harvesting of Skin Autograft for Closure of Excised, Full-Thickness Burns," The Journal of Trauma and Acute Care Surgery, Vol. 60, No. 4, 2006, pp. 821-829.

[69] E. Pianigiani, F. Ierardi, B. Mazzanti, R. Saccardi, C. Cuciti and M. Fimiani, "Human De-Epidermized Dermis as a Stem Cell Carrier," Transplantation Proceedings, Vol. 42, No. 6, 2010, pp. 2244-2246. doi:10.1016/j.transproceed.2010.05.040

[70] T. J. Phillips, "Biologic Skin Substitutes," Journal of Dermatologic Surgery \& Oncology, Vol. 19, No. 8, 1993, pp. 794-800.

[71] W. Marston, J. Hanft, P. Norwood and R. Pollak, "The Efficacy and Safety of Dermagraft in Improving the Healing of Chronic Diabetic Foot Ulcers: Results of a Prospective Randomized Trial,” Diabetes Care, Vol. 26,
No. 6, 2003, pp. 1701-1705. doi:10.2337/diacare.26.6.1701

[72] R. Kumar, R. Kimble, R. Boots and S. Pegg, "Treatment of Partial-Thickness Burns: A Prospective Randomized Trial Using Transcyte ${ }^{\mathrm{TM}}$," ANZ Journal of Surgery, Vol. 74, No. 8, 2004, pp. 622-626. doi:10.1111/j.1445-1433.2004.03106.x

[73] Y. Bello and A. Falabella, "The Role of Graftskin (Apligraf $^{\circledR}$ ) in Difficult-to-Heal Venous Leg Ulcers,” Journal of Wound Care, Vol. 11, No. 5, 2003, pp. 182-183.

[74] J. Hefton, M. Madden, J. Finkelstein and G. Shires, "Grafting of Burn Patients with Allografts of Cultured Epidermal Cells,” Lancet, Vol. 322, No. 8347, 1983, pp. 428-430. doi:10.1016/S0140-6736(83)90392-6

[75] J. Bolivar-Flores, E. Poumian, M. Marsch-Moreno, G. Montes de Oca and W. Kuri-Hascuch, "Use of Cultured Human Epidermal Keratinocytes for Allografting Burns and Conditions for Temporary Banking of the Cultured Allografts,” Burns, Vol. 16, No. 1, 1990, pp. 3-8. doi:10.1016/0305-4179(90)90197-5

[76] A. Brain, P. Purkis, P. Coates, M. Hackett, H. Navsaria and I. Leigh, "Survival of Cultured Allogeneic Keratinocytes Transplanted to Deep Dermal Bed Assessed with Probe Specific for Y Chromosome,” British Medical Journal, Vol. 298, No. 6678, 1989, pp. 917-919. doi:10.1136/bmj.298.6678.917

[77] E. Matousková, L. Broz, V. Stolbová, L. Klein, R. Konigová and P. Vesely, "Human Allogeneic Keratinocytes Cultured on Acellular Xenodermis: The Use in Healing of Burns and Other Skin Defects," Bio-Medical Materials and Engineering, Vol. 16, Suppl. 4, 2006, pp. S63-S71.

[78] M. Madden, J. Finkelstein and G. Shires, "Grafting of Cultured Allogeneic Epidermis on Second- and ThirdDegree Burn Wounds on Twenty-Six Patients," The Journal of Trauma and Acute Care Surgery, Vol. 26, No. 11, 1986, pp. 955-962.

doi:10.1097/00005373-198611000-00001

[79] T. Phillips and B. Gilchrest, "Cultured Allogenic Keratinocyte Grafts in the Management of Wound Healing: Prognostic Factors,” Journal of Dermatologic Surgery \& Oncology, Vol. 15, No. 11, 1989, pp. 1169-1176.

[80] M. Kristin and M. David, "Distinct Epidermal Stem Cell Compartments Are Maintained by Independent Niche Microenvironments," Stem Cell Reviews, Vol. 2, No. 3, 2006, pp. 221-231. doi:10.1007/s12015-006-0050-7

[81] C. Blanpain, W. Lowry, A. Geoghegan, l. Polak and E. Fuchs, "Self-Renewal, Multipotency, and the Existence of Two Cell Populations within an Epithelial Stem Cell Niche," Cell, Vol. 118, No. 5, 2004, pp. 635-648. doi:10.1016/j.cell.2004.08.012

[82] E. Fuchs and V. Horsley, "More than One Way to Skin," Genes \& Development, Vol. 22, No. 8, 2008, pp. 976-985. doi:10.1101/gad.1645908

[83] F Watt, C. Lo Celso and V. Silva-Vargas, "Epidermal Stem Cells: An Update," Current Opinion in Genetics \& Development, Vol. 16, No. 5, 2006, pp. 518-524. doi:10.1016/j.gde.2006.08.006 
[84] D. L. Jones and A. J. Wagers, "No Place like Home: Anatomy and Function of the Stem Cell Niche. Nature Reviews,” Molecular Cell Biology, Vol. 9, No. 1, 2008, pp. 11-21.

[85] D. Zipori, “The Stem State: Plasticity Is Essential, Whereas Self-Renewal and Hierarchy Are Optional,” Stem Cells, Vol. 23, No. 6, 2005, pp. 719-726. doi:10.1634/stemcells.2005-0030

[86] E. Clayton, D. Doupe, A. Klein, D. Winton, B. Simons and P. Jones, "A Single Type of Progenitor Cell Maintains Normal Epidermis,” Nature, Vol. 446, No. 7132, 2007, pp. 185-189. doi:10.1038/nature05574

[87] A. Giangreco, M. Qin, J. Pintar and F. Watt, "Epidermal Stem Cells Are Retained in Vivo throughout Skin Aging," Aging Cell, Vol. 7, No. 2, 2008, pp. 250-259. doi:10.1111/j.1474-9726.2008.00372.x

[88] A. Tausche, M. Skaria, L. Böhlen, et al., “An Autologous Epidermal Equivalent Tissue-Engineered from Follicular Outer Root Sheath Keratinocytes Is as Effective as SplitThickness Skin Autograft in Recalcitrant Vascular Leg Ulcers,” Wound Repair Regen, Vol. 11, No. 4, 2003, pp. 248-252. doi:10.1046/j.1524-475X.2003.11403.X
[89] J. Hafner, A. Kühne and R. Trüeb, “Successful Grafting with Epidex in Pyoderma Gangrenosum,” Dermatology, Vol. 212, No. 3, 2006, pp. 258-259. doi:10.1159/000091255

[90] A. Limat and T. Hunziker, "Use of Epidermal Equivalents Generated from Follicular Outer Root Sheath Cells in Vitro and for Autologous Grafting of Chronic Wounds," Cells Tissues Organs, Vol. 172, No. 2, 2002, pp. 79-85. doi:10.1159/000065615

[91] M. Jeschke, W. Richter and S. Ruf, “Cultured Autologous Outer Root Sheath Cells: A New Therapeutic Alternative for Chronic Decubitus Ulcers," Plastic and Reconstructive Surgery, Vol. 107, No. 7, 2001, pp. 1803-1806. doi:10.1097/00006534-200106000-00027

[92] L. Macri and R. Clark, “Tissue Engineering for Cutaneous Wounds: Selecting the Proper Time and Space for Growth Factors, Cells and the Extracellular Matrix,” Skin Pharmacology and Physiology, Vol. 22, No. 2, 2009, pp. 83-93. doi:10.1159/000178867

[93] G. Naughton, “Skin and Epithelia,” In: R. Lanza, R. Langer and W. Chick, Eds., Principles of Tissue Engineering, Academic Press, Inc., Cambridge, pp. 769-782. 